\title{
Efficacy of Fungicides against Alternaria porri Causing Purple Blotch of Onion
}

\author{
S. Behera ${ }^{1^{*}}$, A.K. Rai ${ }^{2}$ and R. Rout ${ }^{3}$ \\ ${ }^{1}$ Department of Plant Pathology, college of Agriculture, OUAT, Bhawanipatna-766001, India \\ ${ }^{2}$ KVK, Malkanagiri, OUAT, Odisha-764045, India \\ ${ }^{3}$ Department of Economics, college of Agriculture, OUAT, Bhawanipatna, OUAT-766001, India \\ *Corresponding author
}

Ke y w or d s
$\begin{aligned} & \text { Fungicides, Onion, } \\ & \text { Purple blotch, } \\ & \text { Yield. }\end{aligned}$
Article Info
$\begin{aligned} & \text { Accepted: } \\ & 12 \text { October } 2017 \\ & \text { Available Online: } \\ & 10 \text { December } 2017\end{aligned}$

\section{Keywords}

Fungicides, Onion, Purple blotch, 10 December 2017

\section{A B S T R A C T}

The study was carried out Horticultural Research Station, Mondouri, Bidhan Chandra Krishi Viswavidyalaya, Mohanpur, Nadia, West Bengal on Onion cultivar Sukhsagar during the Rabi season of 2013-2014 and 2014-15. Onion (Allium cepa L.) is one of the oldest known and an important vegetable crop grown in India. The onions are regarded as a highly export oriented crop and earn valuable foreign exchange for the country. Though India produces a significant quantity of onions it is not regular and sufficient enough to meet the demands for both domestic requirement and export. The experiment was conducted in a randomized block design with three replications. The fungicides applied as foliar sprays along with sticker were Difenaconazole $25 \mathrm{EC}(0.025 \%)$, Difenaconazole 25 EC (0.05\%), Difenaconazole 25 EC (0.1\%), Chlorothalonil (0.2\%), Mancozeb 75 WP $(0.25 \%)$, Copper oxychlororide $(0.3 \%)$ and untreated control. Though the differences in disease controlling potential of these fungicides are marginal yet differences in the yield were quite pronounced, as sprays with Difenaconazole 25 EC $(0.1 \%)$ resulted in greater yield increase than the other fungicides. Difenaconazole had earlier been reported to be quite effective in controlling purple blotch disease of onion and increase the bulb yield by Sastrahidayat. However, in the present study Difenaconazole 25 EC $(0.1 \%)$ proved to be more promising in management of disease as well as increasing bulb yield.

\section{Introduction}

Onion (Allium cepa L.) is one of the oldest known and an important vegetable crop grown in India. The onions are regarded as a highly export oriented crop and earn valuable foreign exchange for the country. Though India produces a significant quantity of onions it is not regular and sufficient enough to meet the demands for both domestic requirement and export. Amongst the onion producing countries in the world India ranks second in area and production, the first being
China. India being a second major onion producing country in the world has a productivity of 14.2 t.ha $^{-1}$ (Abdelaziz, 2008). Even though India ranks second in area under onions in the world and third in production but its productivity is low as compared to world's productivity, 19.1 t.ha $^{-1}$. Several factors have been identified for the low productivity of onion in India. The most important factors responsible are the diseases like purple blotch of onion, commonly 
prevailing in almost all onion growing areas causing severe outbreak under favourable conditions (Stewart and Fullerton, 1999). Purple blotch disease of onion is a serious menace in onion-producing countries of the world (Ali, 2009; NHRDF, 2012).

Purple blotch is prevalent on leaves and seed stalk of onions and causes serious damage throughout the onion producing area in the country every year and due to this onion production is reduced which adversely affects exports and also results price hike within the country (Vijayalakshmi et al., 2012). Purple blotch of onion caused by Alternaria porri is one among the serious fungal diseases that affect onion, causing heavy yield loss ranging from 2.5 to 87.8 per cent during kharif season. Keeping in view of the above reason management of purple blotch of onion has become an issue in present condition. In this regard experiments were carried out to assess the efficacy of various fungicides applied as foliar spray and their resultant effect on bulb yield.

\section{Materials and Methods}

The investigation was undertaken at Horticultural Research Station, Mondouri, Bidhan Chandra Krishi Viswavidyalaya, Mohanpur, Nadia, West Bengal $\left(23.5^{\circ} \mathrm{N}\right.$ latitude, $89^{\circ} \mathrm{E}$ longitude having an average altitude of $9.75 \mathrm{~m}$ from the sea level) on Onion cultivar Sukhsagar during the Rabi season of 2013-2014 and 2014-15. The crop was planted on a plot (size $3 \mathrm{~m} \times 2 \mathrm{~m}$ ) at a spacing of $15 \mathrm{~cm} \mathrm{x} 10 \mathrm{~cm}$ and recommended horticultural practices were undertaken. The experiment was conducted in a randomized block design with three replications. The fungicides applied as foliar sprays along with sticker were Difenaconazole 25 EC $(0.025 \%)$, Difenaconazole 25 EC (0.05\%), Difenaconazole 25 EC (0.1\%), Chlorothalonil (0.2\%), Mancozeb 75 WP (0.25\%), Copper oxychlororide $(0.3 \%)$ and untreated control.
First spray was started at the initiation of disease in the middle of February followed by three more spray at 15 days intervals. Disease severity was recorded by using 5 point rating scale. For disease severity, 10 plants per replication were randomly selected and PDI per replication will be calculated by using the formula given by Wheeler. Fresh bulb yield also recorded at the time of harvest.

\section{Results and Discussion}

\section{Effects of fungicides on per cent disease control}

The results (Table 1) showed that all the fungicides and their respective doses significantly reduced the disease intensity in comparison to untreated control in all the years and also in pooled mean. In the year 2013-14, different treatment showed different disease intensity and their differences were statistically significant. Among the different treatments, minimum disease intensity (8.44\%) was observed when the plots were sprayed with Difenconazole 25 EC (0.1\%) followed by Difenconazole $25 \mathrm{EC}(0.05 \%)$ (9.87\%), Difenconazole 25 EC (0.025\%) $(11.56 \%)$ and their differences were statistically at par except later two treatments. Maximum disease intensity was observed on plots sprayed with Copper oxychloride $(0.3 \%)$ (14.97\%) followed by Mancozeb 75 WP $(0.25 \%)(14.57 \%)$ and their difference was statistically at par. The maximum percentage of disease reduction was noticed on Difenconazole 25 EC (0.1\%) applied plots $(61.58 \%)$ followed by Difenconazole 25 EC $(0.025 \%)(55.11 \%)$ and minimum in Copper oxychloride $(0.3 \%)(31.90 \%)$ followed by Mancozeb 75 WP (0.25\%) (33.72\%). In the year 2014-15, among the different treatments, minimum disease intensity $(6.71 \%)$ was observed when the plots were sprayed with Difenconazole 25 EC $(0.1 \%)$ followed by Difenconazole 25 EC $(0.025 \%) \quad(8.46 \%)$, Difenconazole 25 EC $(0.05 \%) \quad(9.62 \%)$. Maximum disease intensity was observed on 
plots sprayed with Copper oxychloride (0.3\%) (12.56\%) followed by Mancozeb 75 WP $(0.25 \%)$ (12.21\%), Chlorothalonil (0.2\%) $(11.79 \%)$ and their differences were not statistically significant in reducing the disease. The maximum percentage of disease control was noticed on Difenconazole 25 EC $(0.1 \%)$ applied plots $(67.43 \%)$ followed by Difenconazole 25 EC $(0.025 \%)(58.95 \%)$ and minimum in Copper oxychloride $(0.3 \%)$ (39.05\%) followed by Mancozeb $75 \mathrm{WP}$ $(0.25 \%)(40.71 \%)$. The two year pooled mean showed that, among the different treatments, minimum disease intensity (7.58\%) was observed when the plots were sprayed with
Difenconazole 25 EC (0.1\%) followed by Difenconazole 25 EC (0.025\%) (9.16\%). Maximum disease intensity was observed on plots sprayed with Copper oxychloride $(0.3 \%)$ (13.76\%) followed by Mancozeb 75 WP (0.25\%) (13.39\%), Chlorothalonil (0.2\%) $(13.10 \%)$ and their differences were not statistically significant in reducing the disease. The disease control percentage was also showed different results on different fungicidal applications. This difference was noticed in both the two years and also in pooled mean. The two year pooled mean also produced similar type of disease reduction in comparison to others.

Table.1 Effects of fungicides on per cent disease index and disease control percentage against purple blotch of onion

\begin{tabular}{|c|c|c|c|c|c|c|c|}
\hline \multicolumn{2}{|c|}{ Treatments } & \multicolumn{2}{|c|}{ 2013-14 } & \multicolumn{2}{|c|}{ 2014-15 } & \multicolumn{2}{|c|}{ Pooled } \\
\hline Fungicides & Concentrations & $\begin{array}{l}\text { Percent } \\
\text { disease index } \\
\text { (PDI) }\end{array}$ & $\begin{array}{l}\text { Disease } \\
\text { control }(\%)\end{array}$ & $\begin{array}{l}\text { Percent } \\
\text { disease } \\
\text { index } \\
(\mathrm{PDI})\end{array}$ & $\begin{array}{l}\text { Disease } \\
\text { control } \\
(\%)\end{array}$ & $\begin{array}{l}\text { Percent } \\
\text { disease index } \\
\text { (PDI) }\end{array}$ & $\begin{array}{l}\text { Disease control } \\
(\%)\end{array}$ \\
\hline Difenaconazole 25 EC & 0.025 & 11.56 & 55.11 & 8.46 & 58.95 & 9.16 & 57.03 \\
\hline Difenaconazole $25 \mathrm{EC}$ & 0.05 & 9.87 & 47.42 & 9.62 & 53.30 & 10.59 & 50.36 \\
\hline Difenaconazole $25 \mathrm{EC}$ & 0.1 & 8.44 & 61.58 & 6.71 & 67.43 & 7.58 & 64.50 \\
\hline Chlorothalonil & 0.2 & 14.40 & 34.48 & 11.79 & 42.75 & 13.10 & 38.62 \\
\hline Mancozeb 75 WP & 0.25 & 14.57 & 33.72 & 12.21 & 40.71 & 13.39 & 37.22 \\
\hline Copper oxychlororide & 0.3 & 14.97 & 31.90 & 12.56 & 39.05 & 13.76 & 35.47 \\
\hline Untreated control & - & 21.98 & - & 20.60 & - & 21.29 & - \\
\hline $\mathrm{SE}(\mathrm{m})$ & - & 1.33 & - & 1.16 & - & 0.61 & - \\
\hline $\operatorname{LSD}(p=0.05)$ & - & 2.89 & - & 2.53 & - & 1.58 & - \\
\hline
\end{tabular}

Table.2 Effects of fungicides on yield and economics of onion cultivation against purple blotch disease

\begin{tabular}{|c|c|c|c|c|c|c|c|c|}
\hline \multicolumn{2}{|c|}{ Treatments } & \multicolumn{2}{|c|}{ 2013-14 } & \multicolumn{2}{|c|}{$2014-15$} & \multicolumn{2}{|c|}{ Pooled } & \multirow{2}{*}{$\begin{array}{c}\text { Benefit/co } \\
\text { st ratio }\end{array}$} \\
\hline Fungicides & Concentrations & Yield (ton/ha) & $\begin{array}{l}\text { Increase in } \\
\text { yield over } \\
\text { control \% }\end{array}$ & $\begin{array}{l}\text { Yield } \\
\text { (ton/ha) }\end{array}$ & $\begin{array}{l}\text { Increase } \\
\text { in yield } \\
\text { over } \\
\text { control \% }\end{array}$ & $\begin{array}{l}\text { Yield } \\
\text { (ton/ha) }\end{array}$ & $\begin{array}{l}\text { Increase } \\
\text { in yield } \\
\text { over } \\
\text { control \% }\end{array}$ & \\
\hline Difenaconazole $25 \mathrm{EC}$ & 0.025 & 21.49 & 29.24 & 25.83 & 43.51 & 23.66 & 36.38 & 1.64 \\
\hline Difenaconazole $25 \mathrm{EC}$ & 0.05 & 22.90 & 37.76 & 27.03 & 50.14 & 24.96 & 43.95 & 1.84 \\
\hline Difenaconazole $25 \mathrm{EC}$ & 0.1 & 27.63 & 66.17 & 31.09 & 72.72 & 29.36 & 69.44 & 2.12 \\
\hline Chlorothalonil & 0.2 & 21.38 & 28.57 & 25.12 & 39.53 & 23.25 & 34.05 & 1.63 \\
\hline Mancozeb 75 WP & 0.25 & 21.06 & 26.68 & 24.71 & 37.25 & 22.88 & 31.97 & 1.60 \\
\hline Copper oxychlororide & 0.3 & 22.65 & 36.26 & 26.58 & 47.65 & 24.62 & 41.96 & 1.65 \\
\hline Untreated control & - & 16.63 & - & 18.73 & - & 17.31 & - & 0.93 \\
\hline $\mathrm{SE}(\mathrm{m})$ & - & 0.88 & - & 1.21 & - & 0.64 & - & - \\
\hline $\operatorname{LSD}(p=0.05)$ & - & 1.93 & - & 2.64 & - & 1.38 & - & - \\
\hline
\end{tabular}


Effects of fungicides on yield and economics of onion cultivation

The effect of fungicides that reduced the purple blotch of onion was also reflected ultimately on bulb yield. All the fungicides had increased the bulb yield $\left(\right.$ tha $\left.^{-1}\right)$ differently in comparison to untreated control and their differences were statistically significant. It was observed in both the years and also in pooled mean. In the year 2013-14, maximum bulb yield was harvested on Difenaconazole 25 EC $(0.1 \%)$ applied plots $(27.63 \mathrm{t} / \mathrm{ha})$ followed by Difenconazole 25 EC $(0.05 \%)$ $(22.90 \mathrm{t} / \mathrm{ha})$. The maximum increase in yield over control (\%) was noticed on Difenconazole 25 EC $(0.1 \%)$ applied plots (66.17\%) followed by Difenconazole $25 \mathrm{EC}$ $(0.05 \%)(37.76 \%)$ and minimum in Mancozeb 75 WP $(0.25 \%)(26.68 \%)$ followed by Chlorothalonil (0.2\%) (28.57\%). Similarly, in the year 2014-15, maximum bulb yield was harvested from Difenaconazole 25 EC $(0.1 \%)$ applied plots (31.09t/ha) followed by Difenconazole 25 EC (0.05\%) (27.03t/ha) though they were statistically at par in increasing the bulb yield of onion. Minimum bulb yield was harvested from Mancozeb 75 WP (24.71t/ha) applied plots followed by Chlorothalonil $(0.2 \%) \quad(25.12 \mathrm{t} / \mathrm{ha})$. Similar type of increase in yield over control (\%) wasalso noticed in 2012-13 (Table 2). The two year pooled mean showed maximum bulb yield from Difenaconazole 25 EC $(0.1 \%)$ applied plots (29.63t/ha) statistically significant with Difenaconazole 25 EC $(0.05 \%)(24.96 \mathrm{t} / \mathrm{ha})$. Minimum bulb yield was recorded from Mancozeb 75 WP (22.88t/ha) applied plots followed by Chlorothalonil $(0.2 \%) \quad(23.25 \mathrm{t} / \mathrm{ha})$ though they were statistically at par with each other. The maximum increase in yield over control $(\%)$ was noticed on Difenconazole 25 EC $(0.1 \%)$ applied plots $(69.44 \%)$ followed by Difenconazole 25 EC $(0.05 \%)(43.95 \%)$ and minimum in Mancozeb 75 WP $(0.25 \%)$
(31.97\%) followed by Chlorothalonil $(0.2 \%)$ $(34.05 \%)$. Maximum Benefit Cost ratio was observed from Difenaconazole 25 EC $(0.1 \%)$ applied plots (2.12) followed by Difenaconazole 25 EC (0.05\%) (1.84).

Though the differences in disease controlling potential of these fungicides are marginal yet differences in the yield were quite pronounced, as sprays with Difenaconazole 25 EC $(0.1 \%)$ resulted in greater yield increase than the other fungicides. Difenaconazole had earlier been reported to be quite effective in controlling purple blotch disease of onion and increase the bulb yield by Sastrahidayat. However, in the present study Difenaconazole 25 EC $(0.1 \%)$ proved to be more promising in management of disease as well as increasing bulb yield.

\section{References}

Abdelaziz, H. 2008. Economics of onion production in the Northern part of Omdurman province, Khartoum State" Albuhuth, 12(1): 42-51.

Ali, G.H.M, 2009. "Onion in the Sudan: production- storage- breeding", Publisher University of Khartoum, report in Arabic.

NHRDF (2012) Annual progress report, National Horticulture Mission.

State Ministry of Agriculture, 2013. Annual report, General management of Agricultural Services, field management, Khartoum State report in Arabic.

Stewart A. and Fullerton, B. 1999. Status of onion white rot and management strategies. Commercial- grower. Horticulture and Food Research Institute of New Zealand Ltd, New Zealand, Pp.23-26.

Thaware, D.S., Fugro, P.A., Jadhav, Y.T., Magar, S.V., and Karande, R.A., 2010, in vitro evaluation of different 
fungicides, plant extracts and bio-agents against Alternaria alternata (Fr.) Keissler causing leaf blight of cowpea. Inter J Pl Prot., 3(2): 356-360.

Vijayalakshmi, M., Madhavi, M. and Kavitha, A., 2012, Studies on Alternaria porri (Ellis) Ciferri pathogenic to Onion (Allium cepa L.) Arch. Appl. Sci. Res.,
4 (1): 1-9

Wheeler, B.E.J. (1969). An introduction to plant diseases. John Wiley and Sons Ltd., London.

Wikipedia, 2014. Onion: Biology, production and insect pests of onion. Wikipedia an Inc. USA.

\section{How to cite this article:}

Behera, S., A.K. Rai and Rout, R. 2017. Efficacy of Fungicides against Alternaria porri Causing Purple Blotch of Onion. Int.J.Curr.Microbiol.App.Sci. 6(12): 1520-1524. doi: https://doi.org/10.20546/ijcmas.2017.612.169 